\title{
Reflections on the King of Ascetics (Yatirāja): Rāmānuja in the Devotional Poetry of Vedānta Deśika
}

\author{
Srilata Raman
}

The ocean of Śrīvaișnava literature is vast and it is a humbling scholarly endeavor to realize that the more one works on it, the more there is to discover; thus, any conclusions that one reaches on the intellectual history of the tradition can only be tentative postulations which can and must be superseded by further research. ${ }^{1}$ This being said, it has become increasingly clear that we are seeing a particularly fertile period between Rāmānuja (traditional dates: CE 10171137 CE) and Vedānta Deśika (traditional dates: CE1268-1369 CE): a period when doctrinal ideas are emerging from a wide spectrum of genres-from devotional poetry and hagiographies to commentaries and $k \bar{a} v y a$ literature. We see also that, for instance, when it comes to the issue of the salvational means - the upāya for mokșa - and their definitions, there was in fact much variation and a spectrum of views, without one single overarching version. Thus, to take one example, even within what emerged as a consensus on the significance of prapatti as the more appropriate upāya for the Kali Yuga, as opposed to bhakti, matters were by no means settled in the immediate post-Rāmānuja period as to how to understand the qualifications (angas) for prapatti, or who was qualified for it. ${ }^{2}$

1 In this essay, the transliteration of manipravāla passages is uneven in that I have adhered to the exact wording in the respective printed books, which is often not systematic, sometimes giving the devanāgari letters and sometimes not. All translations are my own.

2 This has been suggested in the tradition particularly of the writings of Meghanādārisūri, a senior contemporary of Vedānta Deśika. Raghavan (1979), in his survey of Viśiștāadvaitic literature post-Rāmānuja, suggests that the principal work of Meghanādārisūri on prapatti, called the Mumukșūpayyasamgraha, is currently lost. I have been able to acquire a copy of a single printed Telugu manuscript with this title which, in the Upodghätah section, points to at least one view of the author, cited as Meghanādārisūri, which is dramatically different from both the mainstream Vațakalai and Tenkalai ācāryas on prapatti. The relevant sentence is: asmin granthe dvitryamśavyatirikteșu bahvaṃśeșu śrīmadvedāntācaryapakșīyair upādeyārthā eva pratipāditā iti bhāti. taditareșv artheșv ayam anyatamah sāmānyaviśeșalakșaṇalakșitaprapattijñāne tadarthānușthāne ca traivarṇikānām evādhikārah na śūdrasya iti. śrīmadvedāntācāryapraṇiteșu grantheșu sapramāṇam prapattẹ̣ sarvādhikāratā yā samarthitā sā tatraiva

(C) SRILATA RAMAN, 2020 | DOI:10.1163/9789004432802_010

This is an open access chapter distributed under the terms of the CC BY-NC 4.o license 1 lata Raman - 9789004432802 
With the wisdom of hindsight, therefore, one could say that it is not at all surprising that a tradition that grappled with such wide divergences would find some of them encapsulated and formalized in the Tenkalai and Vatakalai aștâdaśabhedas by as late as the eighteenth century. The perception of Rāmānuja, as well as ideas regarding his role in the salvation of his community, correspondingly, also change with the other doctrinal divergences that emerge in the Śrivaișnava tradition after him. This topic forms the core of this paper.

Here, I hope to show that there are many points of convergence in the hagiographical understanding of Rāmānuja between what consolidated into the later Vațakalai and Tenkalai ācārya stotra traditions. The primary texts of comparison here are the Irāmānnuja Nūrrantāti (henceforth, IN) of Tiruvarankkattamutanāar, one of the earliest hagiographical/stotra works we have at hand on Rāmānuja (see the next section for some tentative dating), and Vedānta Deśika's Yatiräjasaptati (henceforth, Ys). The paper suggests that we do not see any major doctrinal divergence between the views of Vedānta Deśika and those expressed by Tiruvarankattamutanār. What we are therefore seeing is a consolidated viewpoint regarding Rāmānuja's stature in the tradition as a whole, which remains unchanged through the centuries. Further, I would suggest that both these works see Rāmānuja not simply as any other a cārya of the tradition, but unique in his special role as being central to the salvation of every Śrivaișnava. Nevertheless, there are definite variations of emphasis and hence of doctrinal inflection that can be traced and these, in turn, the paper suggests, feed into eventual soteriological differences in significant ways. Exploring these subtle inflections is also the purpose of this paper.

The paper begins with a brief examination of the motifs regarding Rāmānuja in the $I N$, contextualizing the poem within the history of earlier devotional poetry addressed to the ācārya within the Śrivvaiṣnava tradition. It then proceeds to consider two of the main motifs of the poem relating to Rāmānuja's divinity before turning to the $Y S$ of Vedānta Deśika. It then discusses the dif-

draștaryā. ("In this work, other than with regard to two or three sections, in many sections, only the meanings established by those who adhere to Vedānta Deśika's position have, it seems, been proven. In the case of meanings that differ, there is this one-that, with regard to the knowledge of prapatti characterized by general and special features, as well as in the accomplishment of the meaning of it, only those of the three varnas are qualified, not the śüdra. In the texts authored by Vedānta Deśika the establishment of [the position that] all are qualified for prapatti, together with authoritative proofs, can be seen there [within those texts themselves].") I am currently in the process of having this text transcribed and will begin a study to determine whether something definitive can be said about its authorship. 
ference in emphases of the two poems and concludes with some historical observations about what this might mean for Tenkalai and Vatakalai soteriological doctrine, post-Rāmānuja.

\section{Amutan̄ār's Pirapantam on Rāmānuja}

The Śrivaișnava hagiographical tradition places the author of the $I N$, Tiruvaraṅkattamutanāar or Amutanāra, as he is also referred to, within Rāmānuja's own lifetime. In the hagiography, the Splendour of the Previous Ācāryas (Pūrvācārya Vaibhavam), Prativāti Payañkaram Aṇnanikarācāriyār (1955) states that he was either the father or the grandfather of Piḷai Perumāl Aiyañaanr, the author of the Astaprabandham, who was a disciple of Parāśara Bhațar. Since Bhatțar is traditionally considered to date to the twelfth century, this would place Amutan̄ār within Rāmānuja's own traditional dates of 1017-1137 CE. This is further consolidated by details given in the hagiography of Amutan̄ār. In it, Amutan̄ār is introduced as a recalcitrant employee of the Śrīrangam temple (kōyil kottil uḷ lavar) who first resists but later accepts Rāmānuja's chief disciple Kūrattālvān as his own teacher and, rewarded for this by being made the administrative head of the temple (srīkāryam) by Rāmānuja, subsequently also composes the $I N .^{3}$

The $I N$ is an extensive poem of 108 verses composed in the kalitturaiviruttam metre. In terms of its poetic type it falls within the "super-genre" called pirapantam. Zvelebil $(1974,193)$ has pointed out that the great variety of poetic forms that fall within this category have only this much in common: "the character of a connected narrative with strong elements of description." Traditionally, pirapantams were listed as thirty-six in number but by the eighteenth century, when Beschi wrote his Caturakarāti, the number had increased to ninety-six. ${ }^{4}$ The $I N$ faithfully follows the logic of the genre of Nurrantāti, being a poem of technically one hundred verses (here we actually have eight, auspicious additional verses), in venppa and kalliturai metres in an antāti arrangement, where the last syllable or word of the preceding stanza is identical with the first syl-

3 Aṇnañkarācāriyār $(1955,40)$ : ... irāmānnuca nūrrantāti aruḷicceyta amutan̄ār emperumān̄āruțaiya niyamanattināa ā ânānai ațipanintu tiruntinavar. A further Tamil work attributed to Amutanār is the Tiruppatikkōvai, a poem in Tamil of 40 verses in the kōvai genre of pirapantam literature that is considered to list the 108 sacred places of the Śrivvaișnavas.

4 In effect the pirapantam emerged as the most prolific genre of poetic composition in premodern Tamil literature, outdoing the tanippātal, bhakti poetry and epic/narrative forms. On this see Zvelebil 1974, 194. 
lable or word of the succeeding one. It models itself consciously on the poetry of the ālvars, on the Tiviyappirapantam, and its very specific model is the small work attributed to Maturakavi ālvār, the "Knotted, Fine, Small Rope" (Kannininunciruttämpu), since the latter is the first work of the Tiviyappirapantam where the ācārya himself, rather than Viṣnu-Nārāyaṇa, becomes the object of veneration and worship. ${ }^{5}$ Hence, the Kanninunciruttāmpu functions as a precursor to all subsequent hagiographical stotras on the ācāryas of the tradition. The opening verse of this very short poem of ten verses is:

Sweet it will be, my tongue will fill with nectar in saying, "Nampi of South Kurukūr" after nearing him through my Lord, ${ }^{6}$ the Great Māyan, who allowed himself to be tied by the knotted, fine, small rope. ${ }^{7}$

The verse sets the tone for the entire poem, where the poet seeks out Nammālvār, implicitly seen as the focus of direct devotion rather than Māyōñ/Kṛṣna. In his introduction (avatārikai) to the text, Periyavāccān Pillai (an older contemporary of Vedānta Deśika traditionally dated to the mid-thirteenth century) makes it clear that Maturakavi takes refuge with Nammālvār himself as the person who can most help him when it comes to reaching God, as the person who can bring about the experience of the Blessed One for him (bhagavadanubhavasahakāri $)$ and who, due to helping him in various ways, is himself the object to be aimed at (uddeśya). ${ }^{8}$ There are three motifs in the poem: first, that Nammālvār himself is the direct object of refuge; second, that he has rid the

5 Tiruvaran̉kattamutan̄ār (1999, 1): nālāyirativyaprapantattil "kaṇninuṇ ciruttāpu" nammāâlvār vișayamāka amaintatu pōla emperumān̄ār vișayamāka irāmāñuca nūrrantāti eñappațum tivyaprapantam amaintullatu.

6 The commentators interpret the words "ennappanil nannin" in two different ways. They either take the "il" to be a negative suffix, thereby suggesting that the poet moves away from Māyan towards Nammālvār, or they take it as an ablative suffix, thereby suggesting that he approaches Nammālvār through or via God.

7 Kiruṣnasvāmi Aiyyañkār (1993, 31):

kaṇninnuṇciruttāmpiñāl kațtuṇnap

paṇniyaperumāyan ennappanil

naṇnit tenkurukūr nampiy enrakkāal

annịikkum amut ūrum en nāvokkē.

8 Kiruṣnasvāmi Aiyyañkār $(1993,23)$ : ... prāptitacaiyil pakavatanupavasahakārikalāāyum, ippați pahumukamānna upakārattālē sarvāvastaiyilum tatīyarē uttēcyareñru atyavacittu, tamakku vaiṣnava vișaȳ̄kārattukku munpē ajñātajñāpakamukattālē pakavatvișayattilē mūțțina mahō-

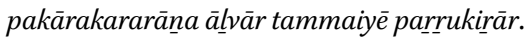


poet of his bad karma/sins, and finally, that he has rendered the Vedas into Tamil. As we proceed to look at the $I N$ we will see that these three motifs as well as the religious assumptions and the contents of the Kanninunciruttämpu both permeate and influence the poem.

The $I N$ itself came to occupy a special place within quotidian Śrīvaiṣnava religiosity. Its significance can be gauged from the fact that, though it is not composed by the $\bar{a} \underline{l} v \bar{a} r s$, it is one of the few anomalous works to be included within the corpus of the Tiviyappirapantam itself, as part of the concluding section of the Iyarp $\bar{a},{ }^{9}$ and hence also a part of the daily cycle of prayersthe nityānusaṃdhānam — for all Śrīvaiṣnavas, both Teñkalai and Vațakalai. A further name attributed to it, and included in Amutanār's traditional hagiography, is Prapannaga ayatri - in other words, that like the Gayatri mantra recited by the twice-born male during the daily morning and evening prayers (samdhyāvandanam), the $I N$ must also be a part of the daily prayer rituals of the one who has undertaken prapatti ( prapanna). ${ }^{10}$ The hagiography of Amutan̄ār points out that the decision to include the $I N$ within the Iyarpa as well as the decision to make it part of the daily prayer cycle of Śrivaiṣnavas was taken by Uțayavar (Rāmānuja) himself, as recorded in the chronicles of the Śrinrangam temple (Kōyil Oluku). ${ }^{11}$

In this brief consideration of this poem, with its verses of simple and elegant beauty, I begin with two examples which show its debt both to the Tiviyappirapantam and to the stotra tradition of the ācāryas generally. In the first example, towards the latter part of the poem, we have the following verse $(76)$ where there is the piling up of examples of all that which is precious and delectable, culminating in the assertion that only Rāmānuja can offer the devotee that which is most precious, which are his feet:

O Rāmānuja!

Enduring fame, expansive waters,

splendid Vēnkațam with its golden summit,

9 The Tiviyappirapantam is traditionally divided into four books of which the Iyarpā, meaning, "short metres," forms the third book. For a detailed discussion of the possible rationale of the arrangement of the poetry into this four-fold division and their internal contents, see Hardy $1983,247-256$.

10 Tiruvaraṅkattamutanār $(1999,2)$.

11 Tiruvaran்kattamutanār $(1999,2)$ : uțaiyavar, nūrrrantātiyai iyarpā̄ōțē-mutalāyirattil kaṇṇinuṇciruttāmpaip pōlè cērttu sakala śrīvaiṣnavarka!̣kkum prapannakāyatrīyāka nityāanusantēyam enrum; inta amutañārukkum tiruppaṇi ceyvārukkum mațamum tirumāḷkai-

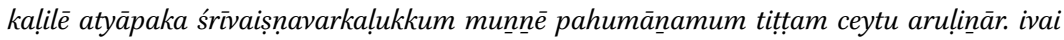
(kōyiloluku) tarum ceytika!. 
the land of Vaikuntha, the celebrated Milk Ocean-

How much pleasure all these give you!

That much pleasure your lotus feet also give me.

Then, grant them, graciously. ${ }^{12}$

Not only does this verse immediately echo for us the opening line of Nammālvār's verse 68 of the Periyatiruvantāti, which begins, "mountains, the groveringed Ocean and the heavenly kingdom of Vaikunțha" (kallum kanaikkațalum vaikunta vā nattum), but even while echoing the prior poem it is doing something entirely novel. In Nammālvār's verse the poet is talking about how Kṛ̣nna, the dark God, has entered his heart and will not be dislodged from it. Hence, all God's usual habitations - the sacred mountain, the Cosmic Ocean and even Vaikunțha itself appear abandoned. Here, in the $I N$, Amutanār seems to suggest that these places where Kṛṣna normally dwells are the very same places which are within Rāmānuja's reach-and give him pleasure. For him, in contrast, he would gladly forsake all these for Rāmānuja's feet.

Verse 92 of the $I N$ turns to another ubiquitous theme in Śrivaișnava prapatti stotras: the unworthiness of the person seeking refuge. Here, in the first two lines Amutanār says, "I have not done the virtuous vows" (punniyanōnpu purintum ilenn), and "I have not spoken the subtle, rare and sacred words" (nunarulkêtvi nuvanrum ilên). These lines resonate for us with the words of another verse of Nammālvār's: Tiruvāymoli 7.5.1 (nōrrananonp illēnn, nuṇnaririv$i(\bar{e} \underline{n})$. We are further reminded of the poetry of another ācārya whose Sanskrit work was also heavily influenced by the Tiviyappirapantam-Āḷavantār's Stotraratna, verse 22: na dharmaniștho'smi na cātmavedī, na bhaktimāms tvaccaranāaravinde.

The $I N$ thus consciously positions itself within this lineage of devotional poetry - showing us that it continues and builds upon doctrinal views regarding God and the ācärya, who are seen as mirror images of each other, just as the poetry of each previous ācārya becomes a template available for embedding, as a literary echo, within the work of a successor. Indeed, the Kanninunciruttāmpu itself becomes a direct source of further emulation in the Manavălamāmunikal Kanninunciruttämpu-a 13-verse poem (circa fourteenth-century) by the lat-

$12 I N$, verse 76 :

niñra vaṇkīrtiyum nīlpuñalum níraivēinkațap

porkuñramum vaikuṇțanāțum kulaviyapārkațalum

unranakk ettanai inpantarum un inaimalarttā!

en tañukkum atu irāmānucā ivai iṇțarulẹ. 
ter's disciple Kōyil Kantātai Aṇṇan̄, which centres on Maṇavālamāmuñi's feet as a refuge because he, in turn, had taken refuge with Nammālvār.

This brings me to one of the main motifs that appears again and again in the poem: the indirect identification of Rāmānuja with Māyōn/Māyavan̄/Kaṇṇan as the dark cloud who brings cool rain and alleviates suffering.

In this regard a few examples from the poem should suffice: "the dark cloud that is Rāmānuja" (irāmānucan enñum kār), in verse 24; in verse 25, "O Rāmānuja, benevolent as a dark cloud" (kārēy karuṇai irāmān̄ucā ); verse 27 speaks of Rāmānuja as that capacious rain cloud that enters the heart of the poet; verses 55 and 60 use the word koṇtal for rain cloud, where Rāmānuja is likened to a cloud pouring out the rain of the Vedas (55), or a rain cloud endowed with good qualities (6o); and verse 83 speaks of his generosity being like a dark rain cloud (kār konța vaṇmai), as does verse 104, likening him to a bountiful rain cloud (celunkonțal). Finally, verses 74 and 104 even suggest, through a kind of poetic hyperbole similar to that which will surface later in the Ācāryahrdayam of Alakiya Maṇavālapperumāl Nāyanaār, ${ }^{13}$ that Rāmānuja, the dark cloud who convinces everyone through cool reason, might even be more effective than Māyavan with his fiery discus - or that even if one were shown Kaṇnan like a gooseberry in the palm of one's hand, one would want nothing other than Rāmānuja's greatness $(c \bar{c} r) \cdot{ }^{14}$

13 The reference here is to $\bar{A}$ cāryahrdayam, sütras $56 \mathrm{ff}$., where the Tiviyappirapantam is compared to a golden vessel and the Vedas to an earthen vessel.

$14 I N$, verse 74:

tērārmaraiyin tiram eñru māyavan tīyavaraik

kūrāli konțu kuraippatu koṇtal anaiya vaṇmai

èrärkuṇatt em irāmānucan avv elilmaraiyil

cērātavarai citaippatu appōtu oru cintai ceytē

Māyavan reduces with the sharp discus

those who don't understand the path of the Vedas.

My Rāmānuja of great qualities

with the strength of a raincloud

destroys those who don't accept the splendid Vedas

merely through a thought.

Verse 104:

kaiyir kañiyennnak kaṇnañaik kātțittarilum uñran

meyyir pirañkiya cīr añri vēnțilan yān nirayat

toyyil kițakkilum cōtivin cērilum iov aru! nī

ceyyil tarippan irāmānucā en celunikoṇtalē

Rāmānuja, my bounteous cloud!

Even if one were to show Kannnan as a fruit in the hand

other than the splendour emanating from your body 
These multiple references to Rāmānuja as a dark, bountiful, compassionate and cooling rain cloud cannot but take us back again to the Tiviyappirapantam and, even prior to it, to the early history of Kṛṣna worship in the Tamil country. As Hardy in his magnum opus Viraha Bhakti has convincingly shown (1983, $149 \mathrm{ff}$.), the earliest references to the God Māyōn come to us from specific verses in the Puranānūru and Pattuppātțu. The word itself, meaning "the dark complexioned one," clearly is the Tamil equivalent of Kṛ̣na and the references from the earliest poetry are to his dark colour, which is compared to the ocean. Hardy masterfully traces the images of Māyōn from these early references through the late Cankam poetry into the use of the akattinai by the $\bar{a} l v \bar{a} r s$. The $I N$ clearly situates itself with this lineage of poetic images and plays with the image of Rāmānuja as both Māyōn, as better than Māyōn, or in a crucial verse I shall come to later, as the incarnation of the weapons of Viṣnu-Nārāyana. There is no doubt that this invocation of Rāmānuja as Kṛ̣ṇa is meant to set the stage for the second ubiquitous motif in the poem — that Rāmānuja has cleansed the poet of his sins by giving him his feet as a refuge.

\section{Rāmānuja as Saviour from Sin and Granter of the Ultimate Goal}

As mentioned previously, the motif of the ācārya saving the disciple appears in the Kanninunciruttammpu already. The relevant verse is number 7 , where Maturakavi âlvār says Nammālvār removed and destroyed his ancient, bad deeds (pantaivalvinai pärriy arulinān). It is this very claim that the $I N$ makes with regard to Rāmānuja. Let me give a few salient examples for this motif in the poem: verse 4 states that Rāmānuja destroys karma, as in the lines, "After making me a substantive thing in this world, he [Rāmānuja] first cut at the root, ageold karma that secreted illusion ..." (ennaip puviyil oru porulākki marul curanta munnaippalavinai vêr aruttu); verse 7 refers to Rāmānuja as he who enables the poet to cross over sin (paliyaik kațattum irāmānnucan); in verse 26 the poet reiterates that Rāmānuja has removed his true defects that are in the form of his terrible sins/karma (en cey vinaiyām meyykurram nïkki); in verse 35 the poet asks how karma could ever shroud him after he has in his memory the lotus feet of Rāmānuja (aruvinai enñai evvāa in inriy ațarppatuvē); verse 41 plays upon the idea of the accessibility of Rāmānuja by pointing out that even when Mādhava

I do not want.

Even if cast into the affliction of Hell,

or reach the Heaven of light,

this grace done by you sustains me. 
is born on earth within each body, as the Inner Dweller, those who not recognize him are able to become his devotees when Rāmānuja incarnates and gives them true knowledge; in verse 45 the poet emphatically declares that there is no other greater desired object than Rāmānuja's feet, and that no one can make them attainable except the feet themselves (pềr oñru marr illai nin caran añri, appēr alittark ārenrum illai marraic caran añri), etc. In verse 66 the poet sets up an analogy that both compares and distinguishes between the generosity of God and Rāmānuja. Mādhava, he says, gives the supreme abode (vānam) to those who pine (naipavar) for him. But this same goal also becomes available to those who have committed grave sins, because these have been removed by Rāmānuja from their hearts (valvinaiyenn mañattil inam kaținta irāmānucañ). These verses build up to a crescendo in verses 71 ("my previous karma was removed due to your gracious conduct," mun cey vinai nī cey vinayatañăl pōntatu) and 77 ("he burnt out my sins at their roots," en vinaikalaivèr pariyak kāyntanan). In verse 94 the poet emphasizes the assurance that Rāmānuja grants right conduct, the wealth of service to God, and the ability to execute this.

In a brief digression it must be added that we cannot fully understand the theological developments on the Tenkalai side, or the Tamil stotra tradition on the $\bar{a} \underline{\underline{v}} \mathbf{a} r \mathrm{rs}$ and $\bar{a} c \bar{a} r y a s$ in particular, without seeing very similar parallel developments on the Tamil Śaiva side. We are speaking of a shared religious and, most importantly, poetic landscape here where there was mutual influence and emulation. Hagiographical pirapantams were composed on the leading religious figures of both traditions. Thus, the Irupa Irupak $t u$, attributed to Aruḷnanti Śivācāriyar (traditional dates: thirteenth century), who is considered one of the foremost disciples of Meykanțar whose work Civañānapōtam (Śivajñanabodham) inaugurates the Tamil Śaiva Siddhānta canon, is a pirapantam poem of 12 verses whose resemblance to the $I N$ is striking. The Irupa Irupaktu equates Meykaṇțār with Śiva himself, his greatness as a guru being such that he can rid devotees of primal impurity (mala). Such parallels between poetic traditions must also be kept in mind when reflecting on the hagiographical traditions linked to Tamil devotional poetry, considered across the sectarian divides.

Careful reading of the poem shows that $I N$ sets up a series of analogies: between Kaṇnạn/Māyōn and Rāmānuja, and between the salvation promised by Kṛṣna in Bhagavadgìtā 18.66, the Caramaśloka, according to which taking refuge with him would remove all sins of the devotee, and the descent of Rāmānuja in the Kali Yuga, which removes the sins of the poet. This analogy is by no means the only one and I do not wish, hereby, to simplify the poem, reducing it to this doctrinal message. Indeed, in other verses the poem suggests that taking refuge at the feet of the devotees of Rāmānuja is equally important, 
or that Rāmānuja is not so much Māyōn as the incarnation of Viṣnu-Nārāyaṇa's weapons. But there is no doubt that many of its verses suggest that Rāmānuja is connected with the promise of the Caramaśloka; and it is this motif, with the direct analogies it draws between Kṛ̣na-Vàsudeva, on the one hand, and Rāmānuja, on other, that is central to the hagiographical impulse of the poem.

But before I expand on what this means for the representation of Rāmānuja from the earliest hagiographical tradition on him, I would like to focus our attention on Vedānta Deśika's 7o verses on the King of Ascetics, the Yatirājasaptati, to see how it might converge or diverge in its representation of Rāmānuja.

\section{The Yatirājasaptati}

The $Y S$ is a poem of remarkable lyrical beauty consisting of a total of 74 verses. Of a very different aesthetic feel than the $I N$, the poem begins with ten verses on the guruparamparā, where the poet salutes his lineage of teachers, beginning with Viṣnu-Nārāyaṇa and concluding with Rāmānuja. It is carefully structured to hold in a dialectical unity the greatness of Rāmānuja, his divine incarnation, on the one hand, and the greatness of his works and his achievements, on the other. The poem moves in circles, again and again, around these two themes, with the additional theme of the greatness of his devotees inserted in some of these circular reflections. Vedānta Deśika tells us, at the very end of the poem why he has composed it (verse 73):

\section{upaśamitakudrșțiviplavānām upanișadām upacāradīpikeyam | kabalitabhagavadvibhūtìyugmām diśatu matiṃ yatirājasaptatir naḥ \|}

May the Yatiräjasaptati, the lamp that aids the Upanișads by which the distortions that are wrong views are extinguished, give us the knowledge that encompasses both the vibhütis of the Blessed One.

Thus in this verse, which is a phala-śruti, Vedānta Deśika makes it clear that the poem is as much about Rāmānuja's feat in composing the Śrībhāșya, thereby giving the right interpretation of the Upanișads, as it is about the greatness of Yatirāja himself. Indeed, Vedānta Deśika makes it clear that Rāmānuja's greatness lies in his composition of the work on Vedānta.

The poem's first ten verses create the context for the exaltation of Rāmānuja. This context is the lineage of teachers (guruparamparā) who preceded him and are listed in the first eight verses of the poem in the following order: Nārāyaṇa, Śrī-Lakṣmī, Viṣvaksena, Nammāl̄vār, Puṇạarīkākṣa (Uyyan̉koṇțār), 
Śrīrāmamiśra (Maṇakkāl Nampi), Yāmuna (Ālavantār) and Mahāpūrṇa (Periya Nampi). In verse 11 Rāmānuja is addressed, for the first time, with the phrase "Lord of the Ascetics" (patim yatīnàm).

It is relevant that this is not the first time in the hagiographical literature that this epithet is used for him. Instead, as the modern commentator of the $Y S$ Vātūla Nīlameghācārya points out, the word is already used for him, as the title bestowed upon him by Lord Varadarāja at Kāñcipuram when he took the vows of an ascetic, according to the hagiographical literature composed contemporaneous to the poem. Here the commentator references the Yatiräjabhairavam, composed by Rāmānuja's immediate disciple Āndhra Pūrṇa (Vaṭuka Nampi) probably around the same time as the $I N$, where this episode is narrated. ${ }^{15}$

When we come to the poem's understanding of the divinity of Rāmānuja we find a wide spectrum of meanings. In verse 12 , which agrees with verse 33 of the $I N$, Rāmānuja is seen as the coming together of all the five weapons of Murāri (aprthakpratipanna yanmayatvaih vavrdhe pañcabhir āyudhair murāreh, $12 \mathrm{~cd})$. In the very next verse, 13 , there is a playful simultaneous narration or śleșa on the victorious activities of both Lord Kṛṣna and Rāmānuja, where the meanings converge in the word Rāmāvarajạ̣, referring both to Yatirāja as well as Kṛ̣ṇa himself as the younger brother of Balarāma, thus establishing identity between the two figures. Verse 27 lauds Rāmānuja as the aggregation of the threefold splendour (samvalita-tridhāman) of Agni (sikhāvān), the moon (aușadhiśsah) and the sun (täpanaḥ). In verse $3^{2}$ Rāmānuja is seen as having the same capacity to offer protection to the world as Viṣvaksena, with the latter's cane staff transformed into his ascetic's rod. ${ }^{16}$ Verse 28 is particularly eloquent in describing and encapsulating all his nurturing and protecting qualities, which are compared to those present everywhere in nature itself-as the mountain from which originate all the streams of knowledge (sakalavidyāvāhinïjanmaśailah), the tree under which the weary traveller wandering in samsāara takes rest (janipathapariṿ̛ttiśrāntaviśrāntiśākhī), the ris-

15 YS (2010, 20):parighnìtaturyāśramasya śrīrāmānujasya bhagavatā śrīvaradarājena yatirāja iti nāma krtam iti guruparamparāprabhāve varnyate. Yatirājabhairavam, verse 50: patnīm parityajya sa vītarāgaḥ śrïdevarājam pranipatya tasmāt | turyāśramam svīkrtavān dadau sa devo 'pi tasmai yatirājanāma $\|$. The use of the epithet Yatiräja was not the prerogative only of the Śrivaișnavas but of the hagiographical traditions of other sectarian groups as well, seeking to exult their ascetic religious founders, as for instance the Madhvas of Vyāsatīrtha. On this see Stoker 2016.

$16 Y s$, verse $32 \mathrm{~cd}$ :

viśvam trātum vișayaniyatam vyañjitānugrahah san vișvakseno yatipatir abhūt vetrasāras tridaṇḍah || 
ing sun that keeps the illusionary darkness of those with distorted views at bay (nikhilakumatimāyāśsarvarībālasūryaḥ) and the full moon that brings to high tide the ocean of the Vedas (nigamajaladhiveläpürnacandrah). Finally, in verse 63 Rāmānuja is Viṣnu himself in his form (mūrtih) as Dattātreya, with his yellow-ochre robes (pitavasanah) and protective ascetic rod. ${ }^{17}$

When we consider the range of figures that Rāmānuja is identified with in the $Y S$ we see that they converge overwhelmingly, with some exceptions, on Viṣṇu-Nārāyana. Thus, the references to him as Agni, the sun and the moon, as the yellow-robed ascetic God, and then, secondarily, as Vișvaksena or the collective of the weapons of Viṣnu, all draw upon images that have a long genealogy in Vedic, epic and Purānic literature on Viṣnu-Nārāyaṇa. If the YS echoes other Vaiṣnavite devotional poetry at all, in addition to the Tiviyappirapantam, we would do well to consider the images of Viṣnu presented in the Paripātal, in the context of the overall Vedicism of the early poetic work..$^{18}$ Thus, despite the commonality between the $I N$ and the $Y S$ in stressing Rāmānuja's divinity, his being elevated to a level above that of the other ācäryas, we see a subtle differentiation in the manner in which the $I N$ foregrounds the significance of the Bhagavadgit ā in contrast to the Vedic, epic and Purānic representations of Viṣnu-Nārāyana in the Ys. This difference in inflection can also be understood if we consider the overwhelming importance that the YS attributes to Rāmānuja's establishment of the "right" kind of Vedānta.

\footnotetext{
17 YS, verse 63ab:

kāṣāyeṇa grhìtapütavasanā daṇdais tribhir maṇditā sā mürtir muramardanasya jayati traiyyantasaṃrakșinī||

18 On this see Raman 2011, 661-662: "A brief comparison of the Tirumāl motifs of the Paripātal with those relating to Viṣnu in the Vedic and immediate post-Vedic Brāhmaṇa and epic literature shows how thoroughly vedicized the Vaiṣnavism of the text is. It would not be unreasonable to speculate that this Vaișnavism of the Paripātal may be drawn from Sanskrit textual sources: the Vedas and Brāhmaṇas, the Mahäbhārata (particularly the Nārāyaṇiya section of the Śāntiparvan) and the Viṣnupurāna. Here, one should draw attention to the following motifs which already appear in these sources: [...] the general description of Tirumāl clad in yellow garments, with the Goddess and the jewel Kaustubha on his chest and, finally and, most importantly, the identification of Tirumāl with elements of the Vedic sacrifice in Paripātal 2.61-64.... There is also the repeated insistence in the text that our only true source of knowledge for Tirumāl's appearance, his deeds, his prowess and his divine grace are the Vedas (called, variously, marai, mutumoli and vāymoli $i$, guarded and transmitted by the Brahmins (antanar)."
} 
There are allusions to Rāmānuja's "protection" of the Vedas, his defeat of those who hold other Vedāntic views as well as the significance of his establishment of the right interpretation of the Vedas in innumerable verses of the Ys. Thus, Rāmānuja's words are a firmly established cage of logic to prevent the wanderings that are the Vedas (v. 14) and they also draw in the texts that are the Vedānta (v. 26). ${ }^{20}$ They cause those who have touched the bed of the Ocean that is the rules of the Vedanta to rejoice, and have them establish the state of salvation. ${ }^{21}$ Rāmānuja, the poem states, is the tridanda-bearing ascetic who sits at the base of the tree of the Vedas, removing the fear of deceitful people from the minds of people (v. 22). ${ }^{22}$ Verse 31 captures in a lovely set of images the nature of Rāmānuja's works. They are wish-fulfilling trees for the imagination of debaters (kathakajanamanīsā-kalpanākalpavrkșāhn), oozing with the nectar of Hari's feet (haripadamakarandasyandinah), possessing many branches (anugatabahuśākhāh) so that they can remove suffering/heat (āpam unmūlayanti), and subduing (with their perfume) the stench of sins (śamitaduritagandhăh).

The repeated reference to the Vedic basis of Rāmānuja's teachings is stressed in several further phrases in verses $44,47,5^{\circ}$, etc. In verse 57 Vedānta Deśika interestingly historicizes the tradition, accepting that even if Rāmānuja's doctrine (mata) is new (navinam) and others might have come before (prāk), this does not matter. For Rāmānuja is within the lineage of those ancient commentators such as Ṭanka, Dramiḍa and Guhadeva, who were fearless (nirätankkāh) because of their unobscured vision (nijamatitiraskāravigamāt). This view of Rāmānuja's central role in the establishment of a new, Viśiștādvaita Vedānta is the second central motif in the poem. Thus, even while we also have verses in the poem that, like in the $I N$, echo the sentiments of taking refuge at the feet of Rāmānuja, such as verses Verse 18, where those who take refuge at the feet of Yatipati become free of $\sin ($ anagh $\bar{a})$ or Verse 20 , where the feet are a

\footnotetext{
$19 Y$ Y, verse 30: śrutinayanasanābhih śobhate lakṣmaṇoktih.

$20 \quad Y S$, verse 14: abahuśrutasaṃbhavaṃ śrutīnām jaratīnām ayathāyathapracāram | vinivartayitum yatîśvaroktir vidadhe tāḥ sthiranītipañjarasthāḥ \| Cf. verse 26a: ākarșaṇāni nigamāntasarasvatīnām 
refuge compared to medicine that stills the fluctuations of the mind (calacittavrttivinivartanauṣadham śaraṇam yatīndracaraṇam vṛnimahe), it becomes clear that the framework of the poem does not allow for a predominant focus on the analogy between Rāmānuja and Kṛ̣na nor that his feet themselves are the predominant upāya for mokșa.

In summing up, we see a common emphasis in the representation of Rāmānuja in the two poems, the one composed in Tamil and the other in Sanskrit separated by centuries. This was a representation rooted in a strong hagiographical, stotra tradition parallel to that of the guruparamparās that emerge from the twelfth century onwards and the various commentaries with hagiographical elements on the Tiviyappirapantam. It reaffirmed Rāmānuja's divine descent, similar to the divine descent of the $\bar{a} \underline{l} v \bar{a} r$ s. It was less uniformly codified, though, as to in what or in whom to locate Rāmānuja's divinity—in Kụṣna himself, in Viṣvaksena or Dattātreya, in Viṣnu-Nārāyaṇa or his weapons. It is also equally clear that from early on the Śrivaișnava tradition was united in seeing Rāmānuja as central to the salvific process, and in considering that, for those who were his disciples, taking refuge in Rāmānuja would accelerate the path to Vaikunțha and the state of servitude (kainkarya) to Viṣnu-Nārāyaṇa. Nevertheless, the frequent references to Rāmānuja as destroying one's sins, a reference directly calqued on the central promise of the Caramaśloka, is not absent but does not function as the fulcrum of the $Y S$ as it does in the $I N$.

Here, we would do well to recollect Vedānta Deśika's poetic tribute to other figures of the guruparamparā in the kārya style, such as his references to Nammālvār in the Pādukāsahasram, the mahākavya of 1008 stanzas that centres around the Rāmāyaṇa episode where Bharata takes the sandals of Rāma on his head and has these reign as the symbol of Rāma's presence, in the latter's absence. Playing in certain verses on the double meaning of the pa $\bar{a} u k \bar{a} s-$ one as the divine sandals and one as Nammālvār himself being the sandals, adorning the feet of God as his ideal devotee-allows the poet to speak of Nammālvar's subordination (śeșatva) as well as his greatness in giving us the Tamil Vedas. ${ }^{23}$ Similar to the treatment of Rāmānuja in the Ys, the Pādukāsahasram section on Nammālvār is careful to place him within the context of the entire guruparampara tradition as someone who performs an extraordinary function in establishing the doctrinal foundations of the school, rather than as a unique figure who towers entirely above all the others of the lineage. Such a perspective, which even while lauding the achievement of each respective ācārya also

23 For a brief analysis of the relevant verses (22-29) of the Pādukāsahasram, see Hardy 1979, 64-67. 
relativizes it within a historical understanding of the tradition, is very different from the affective framework of the $I N$, which dwells on the emotional resonance of a single figure.

\section{5}

\section{Post-Prapatti}

The IN's greater emphasis on Rāmānuja in his role as the ācārya significant for salvation anticipates Tenkalai doctrinal development, as we see it evolving in the works of Piḷlai Lokācārya (traditional dates: CE 1264-1327) and in the commentaries on his works. In his works attention had decisively shifted to a soteriological path that was considered even more appropriate than prapatti for the seeker of salvation - both in terms of being easier as well as the most appropriate expression of the humility of the soul. This new salvific means was "love for the ācārya" - ācāryābhimāna.

In her thorough study of the writings of Manavālamāmuni in the immediate post-Vedānta Deśika period, Mumme (1988) demonstrates the consolidation of the doctrine of ācāryābhimāna as the preferred form of salvation in his commentaries on Piḷai Lōkācārya's works. Summarily put, the doctrine of ācāryābhimāna mirrors, in a mimetic fashion, the reasons why prapatti was favoured above bhaktiyoga in the immediate post-Rāmānuja stage of doctrinal formation. Ācāryābhimāna is not simply for the person incapable of prapatti; it is also "not only a separate means, but the superior or ultimate means (caramopaya), given the ultimate limits of the soul's nature and destiny" (p. 243). The pragmatics of it meant a total surrender of all one's own responsibility for doing anything for salvation by relying on the ācārya to do the needful. What, then, exactly was the ācārya to do? As the commentary of Piḷlai Lōkam Cīyar on Piḷai Lokācārya's Arthapañcakam explains, this meant, in effect, that one surrendered all responsibility for performing prapatti to the ācārya, who out of great compassion and being a great devotee himself, does it for you in your stead and advises you on all your future conduct, so that the prapatti he does for you might prove efficacious. ${ }^{24}$ Thus, as Mumme $(1988,226-227)$ puts it succinctly,

24 Arthapañcakam, Sūtra 9 commentary: "The person who does this ācāryābhimāna is incapable of doing anything else. With regard to him, reflecting on his lowliness and the happiness of the Lord if he were to obtain him, like a mother, who when her child falls ill, sees this as her own fault and gives it medicine, the ācārya is that greatly compassionate one (paramadayālu) and great devotee (mahābhāgavata) who can undertake the means of salvation for the soul. All that the souls has to do is to surrender to the love for him and, 
The only means of salvation in practice today among the Tenkalai is àcāryābhimāna - the love of the ācārya. As they see it, Rāmānuja has already done prapatti to the Lord for all future generations of his followers. Therefore, rather than surrendering to the Lord himself, one merely has to take refuge with an ācarrya of his lineage. For the Vatakalai, the way of salvation is through the performance of prapatti to the Lord in the manner prescribed by the śāstras under the guidance of a qualified $\bar{a} c \bar{r} r y a$. Though the $\bar{a} c \bar{a} r y a$ can perform prapatti specifically for a particular disciple, mere relationship with the ācärya is no substitute for the performance of bharanyāsa [understood in the broadest sense as the laying down of all one's agency] with it's angas.

Hence, she also goes on to point out that there is a widely held belief among contemporary Tenkkalai Śrivvaiṣnavas, not established in any of the writings of Piḷ̣ai Lōkācārya, Maṇavālamāmuñi or Vedānta Deśika, that "Rāmānuja is the àcārya who has saved all future generations of Śrīvaiṣnavas with his prapatti ..." There is a conspicuous textual exception to the absence of this doctrine in the writings of the major ācāryas of both traditions in the thirteenth to fourteenth centuries, though. This is the Caramopāyanirnaya of Nāyanāa Āccān Pilḷai (traditional dates: 1227-1327), the nephew and adopted son of Periyavāccān Piḷ̣ai, a work that clearly endorses the view that taking refuge with Rāmānuja himself is central to salvation, thus making this a doctrinal position found well before contemporary belief. Mumme's arguments $(1988,87-89)$ for doubting that this could be the work of Nāyanāa Āecān Pilḷai is not dissimilar to the controversy regarding Rāmānuja's authorship of the Gadyatraya, which I have addressed in some detail in my 2007 book: stylistically, she suggests it is different (too simple) compared to the same author's other doctrinal works and ideologically it is far too radical for its time, anticipating a doctrine of ācāryabhimāna centred on Rāmānuja which only came much later.

The detailed look I have taken at the Caramopayanirnaya, to be dealt with in another paper, shows a great deal of doctrinal convergence with the $I N$. Indeed, both works in their emotional appeal to Rāmānuja within a salvific framework

[as in the saying], "if you were to give me the certain prize, then we are meant to obtain it", with regard to all his activities do and not do what he [the ācārya] commands."

Arthapañcakam vyākhyāna, p. 68: ācāryāpimānamāōvatu ivayoñukkum caktanañrik-

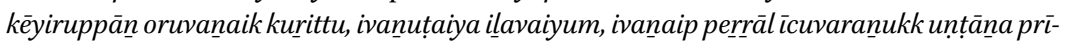

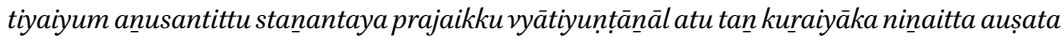
sēvaiyaip paṇnum mātāvaippōlē ivanukkāka tān upāyānușțānam paṇṇi rakṣikavalla paramatayāluvānna makāpākavatan apimānnattilē oțunki, vallaparicu varuvipparēe atu kāṇtum enru collukirapațiyē sakalapravrttinvrttikalaiyum avaniț̣avalakkākkukai. 
allow one to assume that Rāmānuja's salvific qualities, stretching to a point where they can extend over historical posterior time, had become accepted doctrine in at least one important strand of the tradition, even within (if not shortly after) his postulated dates. That Vedānta Deśika, for his part, was also not unaware of these views centred around Rāmānuja becomes clear from a particular passage of his major work on prapatti, the Rahasyatrayasāram. In Chapter 8 of the text, where he is discussing the different categories of those qualified for prapatti (adhikārivibhāga), Vedānta Deśika differentiates between the uktinișthan person, whose prapatti is based upon the utterance taught to them by their ācārya, and the ācāryanișthan person, whose prapatti is done for them by their a āarrya. Regarding this second category of persons, he has this to say:

Among these [two categories], the ācāryanișțan is himself included within the ācārya's laying down of his burden (bharasamarpanam) with regard to him and his own .... For this ācäryanișthan, according to the axiom of "how much more, then" (kaumutika nyāya), there can be no doubt as to the attainment of the fruit. Mutaliyānțān [Rāmānuja's nephew] taught the verse: like those creatures on the body of a lion that leaps from one mountain to another, when Bhāsyakāra [Rāmānuja] jointly leaps [does prapatti], then, due to our bodily relationship with him [i.e. being related to him due to kinship ties], we too have been elevated [we get the same salvific benefits as he does]. ${ }^{25}$

Vedānta Deśika is fully aware that these words attributed to Mutaliyāṇțān are capable of being understood as implying that Rāmānuja's act of prapatti becomes the single soteriological event that saves all those who come after him in the community. Precisely to firmly reject such an understanding he adds, almost immediately, the following emphasis:

In the Nyāsatilakam [verse 21] we also said: "The blind man is able to move about led by the one with sight, O Lord of Śrirangam; the cripple, placed within a boat, is taken across by a boatman; the children of a servant relish [royal] food though they don't know the king; thus will my compassion-

25 Vedānta Deśika (1980, 293-296): ivarkalil ācāryanișthan .... ācāryañuțaiya àtmātmīyabharasamarpaṇattilè tān̄um antarbhūtañ. ... ācāryanișthañukku kaumutikanyāyattālē phalasiddhiyil sandeham illai. oru malayil niñrum oru malaiyilē tāvom simhacarīrattil jantukkalıaippōè bhāsyakārar saṃyoga langhanam paṇna avarōṭ uṇtāña kuṭaltuvakattālēè nāmum uttīrnar à àvuvōm eñru mutaliyāṇțān arulicceyta pācuram. 
ate teacher help me to reach you." The Lord of All will not relent to give the supreme goal without prapatti being done in some way, through some person. ${ }^{26}$

The significant point here is that Deśika is citing poetry of his own to show that the ācārya is the helper, even up to a point where he can do the prapatti for you. What this means that is that it is your current ācārya who can do this for you, and this is what the Nyāsatilakam verse elaborates. This does not mean that Rāmānuja's prapatti at one historical moment absolves his entire community from henceforth doing it. Thus, Vedānta Deśika is concerned to subtly disagree with the statement of Mutaliyāṇțāñ's or at least differs in his interpretation from what it comes to mean later within the Tenkalai tradition.

Ultimately, the doctrinal musings on Rāmānuja are central to a theme that lies at the heart of the tradition: the issue of how to reconfigure the nature of God's and the religious canon's own accessibility to the community of ordinary devotees. Succinctly put, the literature of the Śrīvaiṣnava tradition has repeatedly reconfigured the motif of accessibility both to enable the incorporation of doctrinal change and to allow for canonical expansion. Thus, the central argument in the equation of the Tiviyappirapantam and the Vedas is one of the accessibility of Vedic revelation in a manner that overcomes linguistic, caste and gender boundaries. We see this elaborated in detail for the first time in Nañjīyar's Ārāyirappați vyākhyānam and then more radically reiterated in the Ācāryahṛdayam of Alakiya Maṇavālapperumāl Nāyanāā. The $I N$ is also drawing upon this theme of accessibility—suggesting that Rāmānuja's feet provide the same refuge in the Kali Yuga that Kṛṣna's did in the Dvāpara Yuga. While Vedānta Deśika is determined to pay homage to Rāmānuja's significance within the tradition and sees him as occupying a summit of his own, he is also determined to place him within a framework that establishes the coherence of the school of Visisistādvaita as a whole. The differences between the two poems are reflective of the differences, broadly speaking, in the hermeneutical strategies between the Tenkalai and Vațakalai literature, which Mumme (1988) again summarizes so well: the Tenkalai literature, in general, leans towards hyperbole and dramatic intensity, drawing heavily upon popular idioms and metaphors and rooting itself in the Tamil, devotional poetry. In contrast, in Vedānta Deśika,

26 Vedānta Deśika (1980, 296-297): andho' nandhagrahaṇavaśago yāti rangeśa yadvat, pan்gur naukākuharanihito nīyate nāvikena | bhunikte bhogān aviditanrpạ̣ sevakasyārbhakādịh, tvatsamprāaptau prabhavati tathā deśiko me dayāluh || eṇru nyāsatilakattilē connnōm. Ėtēnnum oru parkaramākavumām, ārēnnum oruvar anuștikkavumām prapattikk allatu sarveśvaran purușārtham koțukka irañkānn eñratāyirrru. 
particularly, we see the need to balance rhetorical flourishes with scholastic precision. He wishes to be seen to be speaking for the coherence of the tradition as a whole, particularly in order that it withstand pan-Vedāntic scholastic scrutiny. For him, homage to Rāmānuja must not lead, through rhetorical excess, to a new and radical turn in the doctrine of prapatti, as it does in the Tenkalai case.

The analysis of the stotra literature on Rāmānuja here, by no means exhaustive but rather exemplary of the formative phase of doctrine, also reinforces for us what has already been established for Rāmānuja's own writings, as in the case of the Gadyatraya: that devotional poetry composed not just by the $\bar{a} \underline{l} v \bar{a} r \mathrm{r}$ but also the later ācäryas is as central as commentaries and independent works to the evolution of Śrīvaiṣnava doctrine.

Finally, it is no mere coincidence that both the Vațakalai and Tenkalai nity $\bar{a}-$ nusaminañam texts begin with a pool of common single, independent verses (taniyan ) of salutation to each figure in turn in one's guruparamparā, which Śrīvaiṣnavas are encouraged to recite on a daily basis. Both contain Kūrattālvāñ's taniyan that ends with the words asmadguror bhagavato 'sya dayaikasindhoh, rāmānujasya caraṇau śarañam prapadye. This convergence in Rāmānuja as the object of veneration speaks for his centrality —as the central gemstone in the necklace of the guruparamparā, as Vedānta Deśika says in his poem (verse 15): a pendant that holds together, gives structure to and makes resplendent not just the individual beads of the necklace but indeed, as the other ācāryas who are themselves likened to the beads of the necklace would say, adorning and forming the dazzling central gemstone of the entire tradition.

\section{Abbreviations}

IN Irāmānuja Nūrrrantāti of Tiruvaranikattamutan̄ār.

ys Yatirājasaptati of Vedānta Deśika.

\section{Acknowledgements}

My thanks go to Elisa Freschi and Marcus Schmücker for their careful reading of the first draft and Harunaga Isaacson for his generous correction of errors and felicitous reformulations of some textual passages. 


\section{References}

Aṇṇan̉karācāriyār, Prativāti Payaṅkaram. 1955. Pūrvācāriya Vaipavam. Kāñcīpuram: Granthamala Office.

Hardy, Friedhelm W. 1979. "The Tamil Veda of a Śudra Saint. (The Śrīvaișṇava Interpretation of Nammālvār)." In Contributions to South Asian Studies, edited by Gopal Krishna, 29-87. Delhi: Oxford University Press.

Hardy, Friedhelm W. 1983. Viraha-Bhakti. The Early History of Krș̣a Devotion in South India. New Delhi: Oxford University Press.

Kiruṣnacuvāmi Aiyyan̉kār, S. 1993. Srīmaturakaviyā lvvār arulicceyta Kaṇninuṇ-cịuttāmpu vyākyānaṅkal. Tiruccirāpaḷi: Puttūr Akirakāram.

Mumme, Patricia Y. 1988. The Śrīvaiṣnava Theological Dispute. Maṇavālamāmuni and Vedānta Deśika. Madras: New Era Publications.

Mumme, Patricia Y. 1998. "The Evolution of the Tenkalai Understanding of the Ācārya: Teacher, Mediator and Saviour." Journal of the Ananthacharya Indological Research Institute 1: 75-98.

Piḷ̂ai Lōkācārya. 2011. Arthapañcakam. With the Commentary of Piḷ̂ai Lōkam Cōyar. Tiruchi: Srīvaiṣṇavasrī.

Raghavan, V.K.S.N. 1979. History of Viśiștādvaita Literature. Delhi: Ajanta Publications. Raman, Srilata. 2007. Self-Surrender (Prapatti) to God in Śrīvaișnavism. Tamil Cats and Sanskrit Monkeys. Routledge Hindu Studies Series. Routledge: London and New York.

Raman, Srilata. 2011. “Tamil, Vaiṣnava, Vaidika: Kiruṣnacuvāmi Aiyañkār, Irāmānuja Tātācāriyār and Modern Tamil Literary History." Journal of Indian Philosophy 39 (6): $647-676$.

Stoker, Valerie. 2016. Polemics and Patronage in the City of Victory: Vyasatirtha, Hindu Sectarianism, and the Sixteenth-Century Vijayanagara Court. California: University of California Press.

Tiruvaraṅkattamutanāār. 1999. Irāmānucanūrrrantāti. Periyacīyar Cōyar aruḷicceyta uraiyum, Piḷ̂ai Lōkācārya Cōyar aruḷicceyta Vyākyānamum. Srīraṅgam: Srīvaișṇavasrī.

Vedānta Deśika. 2010. Yatirāja Saptatiḥ. Vaiyākaraṇamūrdhanyena Kūttapākkaṃ Vātsya Nīlameghācāryeṇa kṛtā saṃskṛtavyākhyā. Srīran̉kam Srīmat Āṇṭavan̄ Āsramaveḷiyịtu.

Vedānta Deśika. 198o. Srimad Vedanta Desika's Srimad Rahasya Trayasara with Sara Vistara (Commentary) by Sri Uttamur T. Viraraghavacharya. Madras: Ubhayavedānta Granthamāla.

Zvelebil, Kamil V. 1974. A History of Indian Literature. Tamil Literature. Wiesbaden: Harrasowitz. 